Fakultas Hukum, Universitas Lampung, Bandar Lampung, Lampung, Indonesia. http://jurnal.fh.unila.ac.id/index.php/corruptio

Volume 02 Issue 1, January-June 2021. PP: 61-72

P-ISSN: 2723-2573 E-ISSN: 2745-9276

\title{
Authority in Handling Criminal Actions Conducted by Law Enforcers
}

\author{
Yustika Rahmawati \\ yustikarahmawati31@gmail.com \\ Lampung Sweeping Community, Indonesia. \\ Rosa Linda \\ rosalindasalamun@gmail.com \\ Lampung Sweeping Community, Indonesia.
}

Submitted: 19 April 2021; Reviewed: 26 April 2021; Accepted: 02 May 2021

Article's Information

Keywords: Authority; Handling; Criminal; Law.

DOI:

https://doi.org/10.25041/corruptio.v2i1.2320
Abstract

The Corruption Eradication Commission (KPK) was not born. However, the handling of criminal acts of corruption is still not maximal, such as the facts found in the field that currently the eradication of corruption is carried out by the prosecutor's office and the police. The purpose of this research is how the authority regulates corruption in Indonesia and corruption crimes committed by law enforcers. This study uses a normative juridical research method in the form of a literature study, and then the data obtained is descriptive qualitative. The results show that the police carry out the criminal act of corruption in Indonesia as the institution that carries out investigations and investigations, the Attorney General's Office as the institution that carries out the prosecution, and the Corruption Eradication Commission as supervision, which sometimes acts directly as an investigator, investigator, and prosecutor in certain cases. Handling criminal acts 


of corruption by law enforcers who are
tasked with assisting the Corruption
Eradication Commission following
Article 11 paragraph (1) letter a and Law
Number 19 of 2019 concerning the
Second Amendment to Law Number 30 of
2002 the Corruption Eradication
Commission.

\section{A. Introduction}

Corruption comes from the Latin word corruption from the verb corrumpere, which means rotten, damaged, shaken, tore, and twisted. Corruption reflects the behavior of public officials, both civil servants and politicians, who illegally and improperly want to enrich themselves by abusing the power that has been entrusted to them. ${ }^{1}$

Corruption crimes that have occurred so far have reached a universal level, not only detrimental to state finances, but this is a violation of the social and economic rights of the community in general and as a whole, so that corruption is essential to be classified as a crime whose eradication must be carried out in an extraordinary comprehensive manner. Corruption as a crime classified as an extraordinary crime is a form of crime that has a systematic crime, organized crime, the reach of the locus and the offense is widespread, causing losses and misery in society, involving many parties from both public and private officials. ${ }^{2}$

The problem of corruption is not new in legal and economic matters for a country. Because the problem of corruption has existed for thousands of years, both in developed and developing countries, including Indonesia. Even the development of corruption in Indonesia is now a huge problem and a very extraordinary problem because it has increased and developed to all levels of society. ${ }^{3}$ The development of corruption in Indonesia is still very high, while its eradication is still very slow. Romli Atmasasmita said that acts of corruption in Indonesia had become a virus that has spread throughout the government since the 1960s, the steps to eradicate it are still slow now. ${ }^{4}$

In Inn 2002 through Law Number 30 of 2002 concerning the Corruption Eradication Commission, the government established the Corruption Eradication Commission or Komisi Pemberantasan Korupsi (KPK) agency corruption cases and is a super body. The establishment of the Corruption Eradication Commission is in the context of increasing the effectiveness and efficiency of efforts to eradicate corruption. ${ }^{5}$ The existence of the Corruption Eradication Commission is also a form of constitutional law politics to eradicate criminal acts of corruption, which are considered extraordinary crimes. Currently, the law governing the Corruption Eradication Commission has undergone renewal, namely by the

\footnotetext{
1 Andjeng Pratiwi and Ridwan Arifin, "PENEGAKAN HUKUM KORUPSI POLITIK DI INDONESIA PERMASALAHAN DAN ISU-ISU KONTEMPORER,” Jurnal Hukum Mimbar Justitia 5, no. 2 (December 30, 2019): 144, https://doi.org/10.35194/jhmj.v5i2.1108. pg 145.

${ }^{2}$ La Niasa et al., "Corruption Eradication In The Perspective Of Criminology," INTERNATIONAL JOURNAL OF SCIENTIFIC \& TECHNOLOGY RESEARCH 5 (2016): 7, www.ijstr.org. pg 125.

${ }^{3}$ Abvianto Syaifulloh, "Peran Kejaksaan Dalam Pengembalian Kerugian Keuangan Negara Pada Perkara Tindak Pidana Korupsi," Indonesian Journal of Criminal Law 1, no. 1 (May 25, 2019): 47-64, https://doi.org/10.31960/ijocl.v1i1.147.

4 Andjeng Pratiwi dan Ridwan Arifin, Op. Cit., 146.

${ }^{5}$ I Nengah Suharta I Gusti Ayu Dwi Andarijati, "PENYIDIKAN TINDAK PIDANA KORUPSI OLEH KOMISI PEMBERANTASAN KORUPSI (KPK) |," Kertha Wicara: Journal Ilmu Hukum, accessed April 26, 2021, https://ojs.unud.ac.id/index.php/kerthawicara/article/view/27960?articlesBySameAuthorPage=3.
} 
promulgation of Law Number 19 of 2019 concerning the Second Amendment to Law Number 30 of 2002 concerning the Corruption Eradication Commission.

Efforts to eradicate corruption in Indonesia are considered unsuccessful, not only because of the thoroughness and rigor of laws and regulations but the implementation and progress of law enforcement officials as an inherent part of law enforcement to eradicate corruption in Indonesia also affects success in eradicating corruption. However, if you pay close attention, Indonesia has made many efforts to eradicate corruption for a long time and throughout Indonesia's history, as evidenced by the emergence of various laws and regulations on corruption eradication. ${ }^{6}$

Efforts to eradicate corruption are not easy things. Even though various efforts have been made to eradicate corruption, there are still several obstacles in eradicating corruption, namely from a structural, cultural, instrumental, and management perspective. ${ }^{7}$ Combating criminal acts of corruption in Indonesia requires a firm commitment to law enforcement so that these crimes do not continue to develop. Police, prosecutors, judges, advocates, and the public must be committed to fighting and eradicating corruption in Indonesia. ${ }^{8}$ What is important in this legal culture, especially in cases of suspected corruption, is a complete and comprehensive understanding of the values that maintain the law, especially those related to criminal acts of corruption, so that it will increase the legal awareness of every individual, both as an apparatus and the general public, of the rights, and its obligations. Corruption eradication will be successful if the public also wants to recognize the values that must be upheld. The public must also realize that the existing system is fair and the legal process is appropriately applied.

Corruption in Indonesia has entered into almost all aspects of public and state life in all government areas, both in the legislative, executive, and judicial fields. ${ }^{9}$ Sometimes criminal acts of corruption are committed by law enforcement officials who should be committed to eradicating corruption. The case of law enforcement officers who are caught in a criminal corruption case that has recently occurred, such as what happened to Arif Fitriawan, an advocate who bribed a judge at the South Jakarta District Court to influence the judge's decision, where the defendant as the plaintiff's attorney wished the panel of judges to grant the claim for the cancellation of the acquisition agreement submitted by the South Jakarta District Court so that the defendant gave money to the judge with Muhammad Ramdhan as the clerk of the East Jakarta District Court, this was decided in the decision of the Central Jakarta District Court Number: 46/Pid.Sus/TPK/2019/PN.Jkt.Pst.

Other cases can also be seen in Decision Number 46/Pid.Sus-Tpk/2020/PN.Jkt.Pst who ensnared the Police members, namely Inspector General of Police. Drs. Napoleon Bonaparte, M. Si. Proven to have committed a criminal act of corruption by accepting bribes from businessmen who are also fugitives. Napoleon deliberately helped in exchange for this money, hoping that Djoko's name would be cleared of the people with a warrant or Daftar Pencarian Orang (DPO) status registered at the Directorate General of Immigration (DG Immigration) or a red notice. That way, when Djoko returns to Indonesia, he can freely enter without being detected by his red notice status.

\footnotetext{
${ }^{6}$ Ridwan Arifin, Indah Sri Utari, and Herry Subondo, "UPAYA PENGEMBALIAN ASET KORUPSI YANG BERADA DI LUAR NEGERI (ASSET RECOVERY) DALAM PENEGAKAN HUKUM PEMBERANTASAN KORUPSI DI INDONESIA," IJCLS (Indonesian Journal of Criminal Law Studies) 1, no. 1 (August 18, 2017): 105-37, https://doi.org/10.15294/ijcls.v1i1.10810.

7 Wicipto Setiadi, "Korupsi Di Indonesia (Penyebab, Bahaya, Hambatan Dan Upaya Pemberantasan, Serta Regulasi)," Jurnal Legislasi Indonesia, accessed April 26, 2021,

8 Faisal Santiago, "Penegakan Hukum Tindak Pidana Korupsi Oleh Penegak Hukum Untuk Terciptanya Ketertiban Hukum," Pagaruyuang Law Journal 1, no. 1 (July 29, 2017): 23-43, www.kpk.go.id/id/berita/siaranpers,.

9 Arie Satria Hadi Pratama, "Eksistensi Peranan Jaksa Dalam Pelaksanaan Pembayaran Uang Pengganti," Corruptio 1, no. 2 (November 10, 2020): 62, https://doi.org/10.25041/corruptio.v1i2.2095.
} 
The problem of corruption does not only occur in the institutions mentioned above but also corruption committed by judges and clerks at the Tangerang District Court Class 1A Special with Decision Number $701 \mathrm{~K} / \mathrm{Pid}$.Sus/2019. Where the two defendants have committed the criminal act of corruption together and continue, Judge Wahyu was detained at the KPK detention center. A judge's salary should have been sufficient to meet the necessities of life. Seeing that some of the cases that have occurred are very alarming, the negative impacts that hinder the functioning of the government as a power of state policy in managing the allocation and holding the state to equal access and assets because along as the dirty broom is not cleaned everything talk about the law is empty. This means that as long as our dirty broom is not cleaned, all legal talk is nonsense. When law enforcement officials provide a good example, the value of trust in law enforcers will run well.

The phenomena or cases above certainly cause distrust in society to law enforcement officers who commit an act that is not commendable. Of course, these things reduce the image, prestige, and good name of law enforcement agencies. Law enforcement officials should provide good examples and role models to society. Based on the description above, the authors are interested in conducting research entitled "Authority in Handling Criminal Actions Conducted by Law Enforcers". So the problem in this research is about how the relationship of authority between law enforcers in handling criminal acts of corruption and how the authority to handle corruption is carried out by law enforcers. The approach to the problem used in this research is a normative juridical approach carried out with a statutory approach, a conceptual approach, and an analytical approach related to criminal cases of corruption committed by law enforcers. The data collection was carried out utilizing a literature study to obtain correct and accurate data in this research. The data obtained were then analyzed descriptively qualitatively.

\section{B. Discussion}

\section{Authority Relations among Law Enforcers in Handling Corruption Crimes}

Since the inception of corruption in Indonesia, there have been institutions dealing with corruption, such as the Indonesian National Police and the Attorney General's Office. However, the above government institutions are considered inefficient and ineffective and have not shown optimal results in Indonesia's corruption cases. Until the ratification of the UN convention, namely the United Nations Convention against Corruption (UNCAC) 2003, which in Article 36 states that Indonesia as a state party must form a particular agency established to deal with corruption cases through law enforcement positive law in Indonesia. Agencies or people, in this case, are given independence/education to carry out their functions effectively and free from intervention from any party. Therefore, Indonesia established the Corruption Eradication Commission, a state institution that is independent and free from the influence of any power in carrying out its duties and authorities.

The formation of this commission aims to increase the effectiveness and results of efforts to eradicate criminal acts of corruption that have been running since before. The Corruption Eradication Commission in carrying out its duties and authorities based on legal certainty, openness, accountability, public interest, and proportionality. ${ }^{10}$ The establishment of the Corruption Eradication Commission institution was not intended to take over eradicating corruption from the existing institutions. The elucidation of the law states that the Corruption

\footnotetext{
10 Mellysa Febriani Wardojo, "KEDUDUKAN KOMISI PEMBERANTASAN KORUPSI SEBAGAI LEMBAGA NEGARA," Legal Standing: Jurnal Ilmu Hukum 2, no. 1 (July 5, 2018): 73, https://doi.org/10.24269/ls.v2i1.1008.
} 
Eradication Commission is a trigger mechanism, which means encouraging or as a stimulus to eradicate corruption by existing institutions are more effective and efficient. ${ }^{11}$

To date, investigations into corruption crimes in Indonesia have been carried out by the Corruption Eradication Commission or Komisi Pemberantasan Korupsi (KPK), the Police, and the Attorney General's Office. The three institutions have the authority to investigate criminal acts of corruption. The difference is the basis for its implementation, namely, the Police and the Attorney General's Office in carrying out their duties and authorities based on the Criminal Procedure Code, while the Corruption Eradication Commission in its investigation is not only based on the Criminal Procedure Code but also Law Number 19 of 2019 concerning the Second Amendment to Law Number 30 of 2002 concerning the Corruption Eradication Commission. ${ }^{12}$

The authority of each sub-system in the criminal justice system is very much determined in the framework of law enforcement, especially in criminal acts of corruption, so that legal certainty and legal equivalence can be achieved. For this reason, it is necessary to have a legal concern about the authority of each sub-system in the criminal justice system, especially in investigations into criminal acts of corruption. If the integrated authority of each sub-system in the criminal justice system is not realized, the public may think that the criminal justice system causes crimes, especially corruption. Moreover, if each sub-system feels that its authority is higher than the other sub-systems, law enforcement efforts on corruption will not achieve the desired target. For this reason, it is necessary to confirm the powers of each subsystem in criminal justice, especially in the investigation of corruption.

The police have the authority as an investigation under Article 6 paragraph (1a) of the Criminal Procedure Code, Article 14 paragraph (1g) of Law Number 2 of 2002 concerning the National Police of the Republic of Indonesia, and Article 25 of Law Number 31 of 1999 concerning Eradication of Corruption Crimes. So, as the sole investigator in the Criminal Procedure Code, the police can still investigate criminal acts of corruption. The Corruption Eradication Commission itself has special authority. Within its organizational structure, some parties act as the police and the Attorney General's Office. The Corruption Eradication Commission can make wiretaps and can file charges directly to the Court. Several years ago, there was a conflict between the Indonesian National Police and the Corruption Eradication Commission. It was as if these two institutions were fighting over the resolution of the corruption case that was ongoing at the time. This conflict is very inappropriate for a law enforcement agency to occur so that the public thinks that there is disharmony in the relationship between law enforcement agencies. ${ }^{13}$

The Attorney General's Office of the Republic of Indonesia also has a very significant role in building a better country, especially in prosecution. However, the prosecutor's office also has the authority to carry out investigations of criminal acts under the laws that are its legal basis. In this case, the enactment of Law Number 16 of 2004 concerning the Prosecutor's Office is regulated in Article 30 paragraph (1) letter d, which states: "The duties and powers of the Prosecutor are "to carry out investigations on certain crimes based on the law". ${ }^{14}$ In its

11 Cindy Rizka and Tirzani Koesoemo, "EKSISTENSI KOMISI PEMBERANTASAN KORUPSI (KPK) DALAM PENANGANAN PENYIDIKAN DAN PENUNTUTAN TINDAK PIDANA KORUPSI," LEX CRIMEN, vol. VI, February 16, 2017, http://www.kpk.go.id/id/berita-sub/2641-kpk-.

12 Masyhudi Masyhudi, "Membangun Sistem Integritas Untuk Pemberantasan Korupsi Dalam Sistem Peradilan Pidana Indonesia," Jurnal Hukum Ius Quia Iustum 26, no. 1 (April 24, 2019), https://doi.org/10.20885/iustum.vol26.iss1.art3.pg 46.

13 Prila Desita Putri and Septi Nurwijayanti, "KEDUDUKAN KPK DALAM TATA NEGARA INDONESIA MENURUT UNDANG-UNDANG NOMOR 19 TAHUN 2019," Media of Law and Sharia 1, no. 3 (August 29, 2020): 187-97, https://doi.org/10.18196/mls.v1i3.9504.

${ }^{14}$ Anonim. Kompilasi Perundangan tentang KPK, Polisi dan Jaksa. Cetakan 1. Pustaka Yustisia. Jakarta. 2010. pg. 119 
explanation, it is stated that what is meant by certain criminal acts based on law areas regulated in Law Number 26 of 2000 concerning Human Rights Courts and Law Number 30 of 2002 concerning the Corruption Eradication Commission. However, in this case, there is also an exception based on Article 284 paragraph (2) of the Criminal Procedure Code. The Criminal Procedure Code has relinquished its investigative authority, and the prosecutor's office is fully assigned to the police. However, Article 284 paragraph (2) as Article "transitional provisions" from the HIR period to the Criminal Procedure Code still leaves investigative authority to the general public as long as it concerns certain crimes, such as economic crimes and corruption. ${ }^{15}$

The Corruption Eradication Commission coordinates with the Supreme Audit Agency, the Financial and Development Supervisory Agency, the State Administrators Wealth Audit Commission, inspectorates in non-departmental government departments or institutions, of course, the Police, the Attorney General's Office, and the judiciary. In Article 33 of Law Number 16 Year 2004 concerning the Attorney General's Office of the Republic of Indonesia, it is stated that: "In carrying out its duties and powers, the prosecutor's office maintains cooperative relations with law enforcement and justice agencies as well as state agencies or other agencies". Likewise, Article 42 paragraph (2) of Law Number 2 of 2002 concerning the State Police of the Republic of Indonesia states that: "Domestic relations and cooperation are carried out especially with elements of regional government, law enforcement, agencies, institutions, other agencies, as well as the community by developing the principles of participation and subsidiarity." 16

Based on these provisions, it can be understood that basically, it has been regulated regarding cooperation between law enforcement agencies in eradicating criminal acts of corruption, especially in this case the Corruption Eradication Commission, the Police and the Attorney General's Office in eradicating corruption in Indonesia. Law enforcers should take advantage of opportunities like this to carry out the countermeasures against corruption. All law enforcement institutions must come together to eradicate corruption in Indonesia.

However, based on the explanation of the new Corruption Eradication Commission Law, the implementation of the duties and powers of the Corruption Eradication Commission, which is different from the provisions of the criminal procedure law, weaknesses in coordination with fellow law enforcement officers, wiretapping problems, poorly coordinated management of investigators and investigators, there is the overlapping authority with various law enforcement agencies, as well as weaknesses in the absence of a supervisory agency that can oversee the implementation of the duties and powers of the Corruption Eradication Commission so that there may be flaws and a lack of accountability in the implementation of duties and authority to eradicate corruption crimes by the Corruption Eradication Commission.

The authority of these three law enforcement agencies has a relationship wherein the corruption investigation system in Indonesia, the existing corruption investigation institutions, namely Police Investigators, Prosecutors' Investigators and Corruption Eradication Commission Investigators have their own system which is regulated in separate laws. The authority of these three law enforcement agencies has a relationship where in the corruption investigation system in Indonesia, the existing corruption investigation institutions, namely

\footnotetext{
15 M.Yahya Harahap. Pembahasan Permasalahan dan Penerapan KUHAP, Penyidikan dan Penuntutan. Edisi Kedua. Sinar Grafika. Jakarta. 2012. Pg 367.

${ }^{16}$ Ibid, 193.
} 
Police Investigators, Prosecutors' Investigators, and Corruption Eradication Commission Investigators, have their system which is regulated in different laws. ${ }^{17}$

Based on the description above, then, this is the reason for the holding of a legal reform regarding the Corruption Eradication Commission by Law Number 19 of 2019 concerning the Second Amendment to Law Number 30 of 2002 concerning the Corruption Eradication Commission, which is expected to make the task each institution in eradicating corruption becomes more systematic. There are no disputes in understanding the authority so that the prevention and eradication of criminal acts of corruption can be carried out effectively and in an integrated manner. The police as the institution that conducts investigations and investigations, the Attorney General's Office as the institution that carries out prosecutions, and the Corruption Eradication Commission as supervision sometimes directly acts as investigator, investigator, or prosecutor in certain cases.

\section{The Authority for Handling Corruption Crimes Conducted by Law Enforcers}

The Corruption Eradication Commission or Komisi Pemberantasan Korupsi (KPK) is an institution or organic commission, namely a commission born from a law. The Corruption Eradication Commission has the duties and authorities stipulated in Article 6 Number 19 of 2019. In addition, the formation of the Corruption Eradication Commission is motivated by the reason that government agencies handling a criminal act of corruption have not functioned properly, efficiently, and effectively in eradicating criminal acts of corruption maximally. ${ }^{18}$ Eradicating criminal acts of corruption according to Law Number 19 of 2019 is an activation process to prevent and eradicate the occurrence of criminal acts of corruption through coordination, supervision, monitoring, investigation, investigation, prosecution, examination in court sessions, with the participation of the community by the provisions of the legislation.

Corruption cases are handled by the Police and the Attorney General's Office in investigation and prosecution. The Corruption Eradication Commission acts as a supervisor that supervises, examines, or examines cases of criminal acts of corruption that have occurred. The Police and the Attorney General's Office are currently carrying out their duties and authorities in eradicating criminal acts of corruption. Later, suppose the Corruption Eradication Commission, in exercising its supervisory authority, finds a situation stated in Article 10A of Law Number 19 of 2019. In that case, the Corruption Eradication Commission has the authority to take over the investigation and/or prosecution of the perpetrators of criminal acts of corruption carried out by the police or attorney. The circumstances that can be used as a reason for taking over an investigation and/or prosecution include::

a. Follow up on public reports regarding criminal acts of corruption;

b. Responsibility for handling criminal acts of corruption that have not been resolved or have been delayed without reason;

c. Protection of the real perpetrators of criminal acts through the handling of criminal acts of corruption;

d. The handling of the criminal act of corruption contains elements of the criminal act of corruption;

e. Interference from the executive, judicative and legislative power holders will become an obstacle to handling corruption crimes; or

\footnotetext{
${ }^{17}$ Mohamad Hidayat Muhtar, "Model Politik Hukum Pemberantasan Korupsi Di Indonesia Dalam Rangka Harmonisasi Lembaga Penegak Hukum," Jambura Law Review 1, no. 1 (January 30, 2019): 68, https://doi.org/10.33756/jalrev.v1i1.1988.

18 dan I Ketut Rai Setiabudhi I Dewa Gede Agung Wira Saputra, "KEWENANGAN SUPERVISI KOMISI PEMBERANTASAN KORUPSI TERHADAP INSTANSI YANG MELAKUKAN PEMBERANTASAN TINDAK PIDANA KORUPSI?," Kertha Wicara: Journal Ilmu Hukum, accessed April 26, 2021, https://ojs.unud.ac.id/index.php/kerthawicara/article/view/53054.
} 
f. Another situation which, according to the consideration of the police or the prosecutor's office, makes it challenging to handle criminal acts of corruption properly and can be justified.

Nowadays, the criminal act of corruption can come from various groups, including the law enforcers themselves, who are supposed to play a role in eradicating the criminal act of corruption. The handling of criminal acts of corruption by law enforcers has differences in terms of the institution that has the authority to carry out investigations, investigations, and prosecutions of criminal acts of corruption in general.

Article 6 letter e of Law Number 19 of 2019 states that the Corruption Eradication Commission is in charge of carrying out investigations, investigations, and prosecutions of criminal acts of corruption. The criminal acts of corruption are intended to have different criteria so that they are not handled by the Police or the Attorney General's Office in their investigation and prosecution. The criteria intended are in Article 11 paragraph 1 letter a and b of Law Number 19 Year 2019, which states that the criminal act of corruption involves law enforcement officials, state officials, and other people who are related to criminal acts of corruption committed by law enforcement officials or state officials, and/or involve state losses of at least Rp1,000,000,000.00 (one billion rupiahs).

The existence of this article makes criminal acts of corruption committed by law enforcers should be handled directly by the Corruption Eradication Commission. There is no need to wait for the process from the police or the prosecutor's office. We can think of this as the government's effort to foster a sense of public trust in handling criminal corruption cases.

Several cases of law enforcement corruption that have been reported recently include the bribery case related to the Joko Tjandra scandal, which ensnared the former Head of the Second Monitoring and Evaluation Sub-Section at the Planning Bureau of the Junior Attorney General for the Development of the Attorney General's Office, Pinangki Sirna Malasari, whose prosecution was carried out by the Attorney General's Office, as well as the former Head of the Criminal Investigation Agency Civil Servant Investigator or Penyidik Pegawai Negeri Sipil Badan Reserse Kriminal Polri (PPNS Bareskrim) Supervision Bureau, Brigadier General Prasetijo Utomo, and the former Kadiv Hubinter Polri, Inspector General Napoleon Bonaparte, as recipients of bribes related to travel documents and the removal of Joko Tjandra's name on the Interpol Polri red notice list whose investigation was carried out by the National Police-Criminal Investigation Unit.

The handling of the case above is, in fact, contrary to what has been stipulated in Article 11 paragraph 1 letter a and b of Law Number 19 of 2019, the Corruption Eradication Commission, which stipulates that investigations, investigations, and prosecutions of criminal acts of corruption involve law enforcement officials. Conducted by the Corruption Eradication Commission. As a result, there were public doubts about the handling of the case.

The doubts that arose over the handling of the case of Attorney Pinangki Sirna Malasari became apparent with the existence of the indictment, which was considered weak, and even negated the existence of Article 55 of the Criminal Code regarding the inclusion that should have been in the indictment, considering that the related case he fabricated was a case that was complicated and most likely involved other officials. ${ }^{19}$ Furthermore, the doubts that have arisen regarding the handling of the cases of Brigadier General Prasetijo Utomo and Inspector General Napoleon Bonaparte are in the verdicts that are considered too light when compared to other corruption cases so that they seem to underplay the meaning of corruption crimes committed by the two high-ranking police officers. In another case, a village head of Wanakaya, Indramayu, West Java, was sentenced to 4 (four) years in prison due to corruption which caused losses to state finances in Rp 168.000.000,00 (one hundred and sixty-eight

\footnotetext{
${ }^{19}$ https://koran.tempo.co/read/editorial/458217/dakwaan-lemah-untuk-jaksa-pinangki-dalam-kasus-joko-tjandra?,
} accessed 9 April 2021. 
million rupiahs). Meanwhile, the two high-ranking police officers, Brigadier General Prasetijo Utomo and Inspector General Napoleon Bonaparte, were sentenced to respectively 3 (three) years 6 (six) months, and 4 (four) years in prison for committing a criminal act of corruption that cost the state Rp 8.400.000.000,00 (eight billion four hundred million rupiahs). Indonesia Corruption Watch (ICW) considers the appropriate verdicts to be imposed on Brigadier General Prasetijo Utomo and Inspector General Napoleon Bonaparte. Both of them are also eligible for a fine of IDR 1.000.000.000,00 (one billion rupiahs). ${ }^{20}$

Data on corruption cases handled by the Corruption Eradication Commission had more than 313 regional heads involved in corruption, and from January to July 2018, 19 regional heads were named as suspects by the KPK for being involved in corruption. Of the legislative members, there have been more than 145 DPRD members throughout Indonesia, spread across 13 provisions processed in corruption cases. If you add the DPR, more than 2020 people have been processed. Meanwhile, up to 2019, the police agency has uncovered a total of 768 cases and saved state funds amounting to Rp. 1.8 trillion. In the police, the handling of corruption cases at the national level is marked by the Directorate of Corruption Crime, Bareskrim, Police Headquarters. There are 25 corruption cases targeted during 2020. Meanwhile, at the provincial level, the targets set vary. There are Polda which target only 2 cases per year and even up to 47 cases per year. Polres at the district and city level also experienced a similar case of up to 12 corruption cases. Looking at the data, it is very worrying about the relationship between politics, money, and corruption. In the era of democratization, corruption and money politics are interrelated. In general, the sources of political support built by politicians are obtained through corruption. This means that if one day a politician manages to gain a political position, he will commit corruption to replace the baiya that has been used to achieve his political goals. ${ }^{21}$

The position of the Corruption Eradication Commission has excessive independence with the Police and the Attorney General's Office. This institution has the authority of the Police and the Attorney General's Office, namely the authority to carry out investigations, investigations, and prosecutions in criminal acts of corruption. The Police and the Attorney General's Office are relatively less independent in carrying out their duties because these two institutions are in the executive power structure. Therefore institutions will experience a problem between judicial functions and duties and political interests, namely when carrying out law enforcement functions and duties in the face of orders from the executive instead of these functions and duties. ${ }^{22}$ Although the Corruption Eradication Commission is also in the executive power clump, in carrying out its duties and powers, the Corruption Eradication Commission remains independent and free from the influence of any power, under Article 3 of Law Number 19 of 2019. Position in executive power is meaningless make the Corruption Eradication Commission not independent and free from the influence of any power. This is reinforced by the decision of the Constitutional Court Number 012-016-019/PUU-IV/2006 previously, where the Constitutional Court stated that the independence and freedom of the KPK from any influence of power was limited to carrying out its duties and powers. ${ }^{23}$

Article 11 paragraph (2) and (3) Law Number 19 Year 2019 states that if the criminal act of corruption does not comply with the provisions referred to in paragraph (1), the Corruption Eradication Commission is obliged to submit investigations, investigations, and prosecutions

\footnotetext{
${ }^{20}$ https://www.republika.co.id/berita/qptdox409/icw-bandingkan-vonis-prasetijonapoleon-dengan-kasus-kades, accessed 9 April 2021.

21 TB. Massa Djafar, Krisis Politikdan Proposisi Demokratisasi: Perubahan Politik Orde Baruke Reormasi, Jakarta, Bumi Aksara, 2015,pg. 191.

${ }^{22}$ Mohamad Hidayat Muhtar, Op. Cit., 82.

${ }^{23}$ Oly Viana Agustine, Erlina Maria Christin Sinaga, and Rizkisyabana Yulistyaputri, "Politik Hukum Penguatan Kewenangan Komisi Pemberantasan Korupsi Dalam Sistem Ketatanegaraan,” Jurnal Konstitusi 16, no. 2 (July 11, 2019): 313, https://doi.org/10.31078/jk1626. PG 324.
} 
to the police and/or attorney. Meanwhile, the Corruption Eradication Commission supervises investigations, investigations, and/or prosecutions as referred to in paragraph (2). However, the two examples of handling criminal acts of corruption above clearly involve law enforcement officials. The handling of these cases should still be under the authority of the Corruption Eradication Commission. If carried out under applicable regulations, the law enforcement process will provide a sense of security for the community as a form of legal protection. Thus, it is normal for public doubts to arise regarding handling corruption crimes that are not adequately handled. For this reason, it is necessary to recall that the presence of the Corruption Eradication Commission is a form of hope to restore public confidence in eradicating corruption in Indonesia.

\section{Conclusion}

Based on the description above, the conclusion is that the police carry out the handling of corruption in Indonesia, the Attorney General's Office, and the Police, the Corruption Eradication Commission. The Police act as an institution that conducts investigations and investigations, the Attorney General's Office acts as an institution that carries out prosecutions, and the Corruption Eradication Commission acts as supervision which sometimes acts directly as an investigator, investigator, or prosecutor in certain cases to jointly achieve law enforcement and eradicating criminal acts of corruption. Then the authority in handling criminal acts of corruption in law enforcers should be handled by the Corruption Eradication Commission following Article 11 paragraph 1 letter a and b of Law Number 19 of 2019 concerning the Second Amendment to Law Number 30 of 2002 concerning the Corruption Eradication Commission. However, in practice, the handling of corruption cases in law enforcers is still handled by the Police and the Attorney General's Office.

The advice given is that law enforcers in eradicating criminal acts of corruption pay attention to good coordination. There is no overlapping authority in eradicating criminal acts of corruption. The Corruption Eradication Commission should be given more opportunities to play its role as corruption eradication commissioner.

\section{Bibliography}

\section{A. Book}

M.Yahya Harahap. Pembahasan Permasalahan dan Penerapan KUHAP, Penyidikan dan Penuntutan. Edisi Kedua. Jakarta: Sinar Grafika. 2012.

TB. Massa Djafar. Krisis Politikdan Proposisi Demokratisasi: Perubahan Politik Orde Baruke Reormasi, Jakarta: Bumi Aksara. 2012.

\section{B. Journal}

Agustine, Oly Viana, Erlina Maria Christin Sinaga, and Rizkisyabana Yulistyaputri. "Politik Hukum Penguatan Kewenangan Komisi Pemberantasan Korupsi Dalam Sistem Ketatanegaraan." Jurnal Konstitusi 16, no. 2 (July 11, 2019): 313. https://doi.org/10.31078/jk1626.

Arifin, Ridwan, Indah Sri Utari, and Herry Subondo. "UPAYA PENGEMBALIAN ASET KORUPSI YANG BERADA DI LUAR NEGERI (ASSET RECOVERY) DALAM PENEGAKAN HUKUM PEMBERANTASAN KORUPSI DI INDONESIA.” IJCLS (Indonesian Journal of Criminal Law Studies) 1, no. 1 (August 18, 2017): 105-37. https://doi.org/10.15294/ijcls.v1i1.10810.

I Dewa Gede Agung Wira Saputra, dan I Ketut Rai Setiabudhi. "KEWENANGAN 
SUPERVISI KOMISI PEMBERANTASAN KORUPSI TERHADAP INSTANSI YANG MELAKUKAN PEMBERANTASAN TINDAK PIDANA KORUPSI? ." Kertha Wicara: Journal Ilmu Hukum. Accessed April 26, 2021. https://ojs.unud.ac.id/index.php/kerthawicara/article/view/53054.

I Gusti Ayu Dwi Andarijati, I Nengah Suharta. "PENYIDIKAN TINDAK PIDANA KORUPSI OLEH KOMISI PEMBERANTASAN KORUPSI (KPK) |.” Kertha Wicara : Journal Ilmu Hukum. Accessed April 26, 2021. https://ojs.unud.ac.id/index.php/kerthawicara/article/view/27960?articlesBySameAuthor Page $=3$.

Masyhudi, Masyhudi. "Membangun Sistem Integritas Untuk Pemberantasan Korupsi Dalam Sistem Peradilan Pidana Indonesia.” Jurnal Hukum Ius Quia Iustum 26, no. 1 (April 24, 2019). https://doi.org/10.20885/iustum.vol26.iss1.art3.

Muhtar, Mohamad Hidayat. "Model Politik Hukum Pemberantasan Korupsi Di Indonesia Dalam Rangka Harmonisasi Lembaga Penegak Hukum." Jambura Law Review 1, no. 1 (January 30, 2019): 68. https://doi.org/10.33756/jalrev.v1i1.1988.

Niasa, La, H M Said Karim, Andi Sofyan, and Syamsuddin Muchtar. "Corruption Eradication In The Perspective Of Criminology." INTERNATIONAL JOURNAL OF SCIENTIFIC \& TECHNOLOGY RESEARCH 5 (2016): 7. www.ijstr.org.

Pratama, Arie Satria Hadi. "Eksistensi Peranan Jaksa Dalam Pelaksanaan Pembayaran Uang Pengganti." Corruptio 1, no. 2 (November 10, 2020 ): 62. https://doi.org/10.25041/corruptio.v1i2.2095.

Pratiwi, Andjeng, and Ridwan Arifin. "PENEGAKAN HUKUM KORUPSI POLITIK DI INDONESIA PERMASALAHAN DAN ISU-ISU KONTEMPORER.” Jurnal Hukum $\begin{array}{lllllll}\text { Mimbar Justitia 5, no. } 2 \text { (December } & \text { 30, } & \text { 2019): }\end{array}$ https://doi.org/10.35194/jhmj.v5i2.1108.

Putri, Prila Desita, and Septi Nurwijayanti. "KEDUDUKAN KPK DALAM TATA NEGARA INDONESIA MENURUT UNDANG-UNDANG NOMOR 19 TAHUN 2019.” Media of Law and Sharia 1, no. 3 (August 29, 2020): 187-97. https://doi.org/10.18196/mls.v1i3.9504.

Rizka, Cindy, and Tirzani Koesoemo. "EKSISTENSI KOMISI PEMBERANTASAN KORUPSI (KPK) DALAM PENANGANAN PENYIDIKAN DAN PENUNTUTAN TINDAK PIDANA KORUPSI." LEX CRIMEN. Vol. VI, February 16, 2017. http://www.kpk.go.id/id/berita-sub/2641-kpk-.

Santiago, Faisal. "Penegakan Hukum Tindak Pidana Korupsi Oleh Penegak Hukum Untuk Terciptanya Ketertiban Hukum.” Pagaruyuang Law Journal 1, no. 1 (July 29, 2017): 23-43. www.kpk.go.id/id/berita/siaran-pers,.

Syaifulloh, Abvianto. "Peran Kejaksaan Dalam Pengembalian Kerugian Keuangan Negara Pada Perkara Tindak Pidana Korupsi." Indonesian Journal of Criminal Law 1, no. 1 (May 25, 2019): 47-64. https://doi.org/10.31960/ijocl.v1i1.147.

Wardojo, Mellysa Febriani. "KEDUDUKAN KOMISI PEMBERANTASAN KORUPSI SEBAGAI LEMBAGA NEGARA." Legal Standing : Jurnal Ilmu Hukum 2, no. 1 (July 5, 2018): 73. https://doi.org/10.24269/ls.v2i1.1008.

Wicipto Setiadi. "Korupsi Di Indonesia (Penyebab, Bahaya, Hambatan Dan Upaya Pemberantasan, Serta Regulasi).” Jurnal Legislasi Indonesia. Accessed April 26, 2021. https://e-jurnal.peraturan.go.id/index.php/jli/article/view/234.

\section{Internet}

https://koran.tempo.co/read/editorial/458217/dakwaan-lemah-untuk-jaksa-pinangki-dalamkasus-joko-tjandra?, accessed on 9 April 2021. 
https://poskota.co.id/2020/8/20/oknum-penegak-hukum-terjerumus-korupsi-idealnyaditangani-kpk accessed on 9 April 2021.

https://www.republika.co.id/berita/qptdox409/icw-bandingkan-vonis-prasetijonapoleondengan-kasus-kades accessed on 9 April 2021. 